\title{
PREVENTION OF INJURY TO TREE SEEDLINGS DURING CELLAR STORAGE ${ }^{1}$
}

\section{BY J. WILNER ${ }^{2}$ and $O$. VAARTAJA ${ }^{3}$ \\ J. WILNER}

Jacob Wilner received his B.S.A. from the University of Saskatchewan in 1936 and his M.S. and Ph.D. in Horticulture and Plant Physiology from the University of Minnesota in 1947 and 1952. He was Tree Planting Supervisor 1937-1947, and Plant Physiologist 1947-1956 at the Forest Nursery Station, Indian Head, Sask. In 1956 he was transferred to the Horticulture Division, Central Experimental Farm, Ottawa, Ontario, to study hardiness in fruit trees.

\section{O. VAARTAJA}

Olli Vaartaja obtained his Doctor's degree at Helsinki University in 1951, with silviculture as his major subject. From 1945 to 1951 he conducted silvical, ecological, and forest pathological research for the Finnish Government, mainly at the Institute of Plant Biology and Plant Pathology of Helsinki University. In 1951-1952 he held a post-doctoral fellowship at Yale. Since 1952 he has been employed at the Forest Pathology Laboratory, Saskatoon, where his special field of research is diseases of seedlings.

\section{$A B S T R A C T$}

Survival of tree planting stock following cellar storage by various methods was consistently good when the storage method included packing the roots in damp peat. Manitoba maple and American elm needed such protection more than caragana and green ash. Prestorage treatments with various fungicides increased survival only slightly, or were injurious. It was demonstrated that injurious desiccation of stored plants may be determined by electrolytic methods.

\section{INTRODUCTION}

Nursery stock grown for distribution to Prairie farms is commonly stored in cellars during the winter before being shipped. Frequently, when planted in the spring many plants die. If the seedlings are heeled in out-ofdoors in the fall, they are protected by the winter snow and survive well, but they cannot be handled early in the spring. Many of the cellar-stored plants become moldy before distribution. Weakly parasitic fungi are reported to cause molding and losses of nursery stock stored over winter under unfavorable conditions (1). Stock stored at 30 to $38^{\circ} \mathrm{F}$. remains dormant, but relative humidity of 85 to 90 per cent is needed to prevent drying (2). At a uniform temperature of 28 to $30^{\circ} \mathrm{F}$., drying is reduced and mold growth is decreased (4). Refrigeration is an excellent method of storing seedlings and cuttings $(3,6)$.

The object of this investigation was to establish a simple method for controlling winter storage injury. The study was designed to determine mainly

\footnotetext{
${ }^{1}$ Joint contribution No. 897 from Horticulture Division, Experimental Farms Service, and No. 403 from Forest Biology Division, Science Service, Department of Agriculture, Ottawa, Canada.

${ }^{2}$ Plant Physiologist, Forest Nursery Station, Indian Head, Sask. Present address: Horticulture Division, Central Experimental Farm, Ottawa, Canada.

${ }^{3}$ Forest Biologist, Forest Pathology Laboratory, Saskatoon, Sask.
} 
if the low survival of the cellar-stored plants was caused by drying out or by molding.

\section{Materials AND Methods}

The experimental material consisted of seedlings of caragana (Caragana arborescens Lam.), green ash (Fraxinus pennsylvanica var. lanceolata Sarg.), box-elder or Manitoba maple (Acer negundo L.), and American or white elm (Ulmus americana L.). In one experiment (B), seedlings of Scots pine (Pinus sylvestris L.) and cuttings of cottonwood (Populus deltoides Marsh.) and Volunteer (a natural hybrid of Populus spp.) were also used. Five replicated bundles, 50 plants in each, constituted a sample of each species.

In accordance with usual practice, the planting stock was stacked during winter along the walls of a storage cellar at Indian Head, Saskatchewan. This is a nonrefrigerated, humid, concrete-walled cellar under a building. The temperatures were controlled by manipulating openings to outdoors when needed. During winter the cellar temperatures were maintained at approximately $30^{\circ} \mathrm{F}$. in one compartment and $35^{\circ}$ and $40^{\circ} \mathrm{F}$. in others. Temperatures were somewhat higher in spring.

The plant samples were treated by various methods of storage (Expt. A) and by fungicides (Expt. B). In spring the plants were planted at 1 -ft. intervals in random rows $9 \mathrm{ft}$. apart. Survival was recorded the following fall. The percentage data were transformed into angles before analysis.

In Expt. A, repeated for 4 years, the roots in each sample were either packed in moist peat or left without protection other than that provided by the surrounding bundles. The peat was partially decomposed acid Sphagnum moss, commonly sold as "peat moss". Heeling in out-of-doors in nursery clay loam served as a check treatment.

In Expt. B, conducted in only one year, the cuttings and roots of the seedlings were dipped for one minute in fungicidal water suspensions and then stored at $40^{\circ} \mathrm{F}$. The fungicides compared were: Tersan (thiram 75 per cent), Orthocide (captan 75 per cent), and Manzate (maneb 70 per cent), each at $25 \mathrm{gm} . / \mathrm{gal}$., lime sulphur at $75 \mathrm{gm} . / \mathrm{gal}$. and Semesan at $14 \mathrm{gm} . / \mathrm{gal}$. Only pine and the poplars were packed in peat in Expt. B. At the end of the storage period, surface-sterilized pieces of plant tissues were plated on agar. The platings were incubated at low temperatures to isolate any low temperature pathogens which might be present.

Because elm was included in Expt. $A$ in two years only, separate analyses were made on data with and without elm. However, very little difference was found in results. Therefore, data on elm are shown in Tables 1 and 2 as comparable to all the other data, but the significant differences given are those derived from the 4 years' data without elm.

The samples were weighed at the beginning and end of storage to determine any change in weight. The electrical conductivity of water extracts of all broadleaved seedlings, those stored with and without peat at the two cellar temperatures and those heeled in out-of-doors, was determined in 1954. The electrical conductivity method was the same as had been used to determine freezing injury in an earlier study (8). 


\section{EXPERIMENTAL RESULTS}

Table 1 shows that the survival of all plants protected by damp peat was approximately equal to the survival of heeled-in plants, and survival of plants stored without this protection was much less. There was little difference in the survival of plants stored at the two temperatures.

Table 2 shows that there was little difference in loss of weight between seedlings heeled in out-of-doors and those stored with peat around their roots. All seedlings without peat lost six to seven times as much weight as the protected seedlings. Weight loss at the two temperatures differed little.

Of the five fungicides, only Orthocide significantly increased plant survival (Table 3). However, as compared with the effect of peat (Table 1),

TABLE 1

Field Survival (Per cent) of Seedlings after Winter Storage in Cellar

\begin{tabular}{|c|c|c|c|c|c|c|c|}
\hline \multirow{3}{*}{ Species } & \multirow{3}{*}{$\begin{array}{c}\text { Year } \\
\text { of } \\
\text { planting }\end{array}$} & \multirow{3}{*}{$\begin{array}{l}\text { Heeled } \\
\text { in out- } \\
\text { of-doors }\end{array}$} & \multicolumn{4}{|c|}{ Winter cellar storage } & \multirow[b]{3}{*}{ Mean } \\
\hline & & & \multicolumn{2}{|c|}{ Peat around roots } & \multicolumn{2}{|c|}{ No peat } & \\
\hline & & & $40^{\circ} \mathrm{F}$ & $35^{\circ} \mathbf{F}$ & $40^{\circ} \mathrm{F}$. & $35^{\circ} \mathrm{F}$ & \\
\hline \multirow[t]{5}{*}{ Caragana } & 1951 & 63 & 96 & 96 & 82 & 89 & 85 \\
\hline & 1952 & 98 & 100 & 100 & 98 & 86 & 96 \\
\hline & 1953 & 100 & 99 & 100 & 98 & 96 & 99 \\
\hline & 1954 & 95 & 95 & 93 & 60 & 76 & 84 \\
\hline & Mean & 89 & 97 & 97 & 84 & 87 & 91 \\
\hline \multirow[t]{5}{*}{$\overline{\text { Ash }}$} & 1951 & 98 & 100 & 98 & 92 & 94 & 96 \\
\hline & 1952 & 99 & 100 & 100 & 98 & 97 & 99 \\
\hline & 1953 & 100 & 100 & 100 & 81 & 55 & 87 \\
\hline & 1954 & 95 & 94 & 97 & 13 & 39 & 68 \\
\hline & Mean & 98 & 98 & 99 & 71 & 71 & 87 \\
\hline \multirow[t]{5}{*}{$\overline{\text { Box-elder }}$} & 1951 & 95 & 97 & 96 & 32 & 37 & 71 \\
\hline & 1952 & 97 & 97 & 90 & 48 & 19 & 70 \\
\hline & 1953 & 100 & 100 & 100 & 13 & 2 & 63 \\
\hline & 1954 & 96 & 89 & 71 & 2 & 12 & 54 \\
\hline & Mean & 97 & 96 & 89 & 24 & 17 & 64 \\
\hline \multirow[t]{3}{*}{$\overline{\mathrm{E}} \mathrm{lm}$} & 1953 & 96 & 96 & 98 & 37 & 34 & 72 \\
\hline & 1954 & 92 & 98 & 96 & 6 & 21 & 63 \\
\hline & Mean & 94 & 97 & 97 & 21 & 27 & 67 \\
\hline \multirow[t]{2}{*}{ Mean } & & 94 & 97 & 95 & 54 & 54 & 77 \\
\hline & & & & & \multicolumn{2}{|c|}{ P. .05} & P. .01 \\
\hline \multicolumn{5}{|c|}{ L.S.D. between means of species } & \multicolumn{2}{|c|}{2} & 3 \\
\hline & $"$ & treatmer & & & \multicolumn{2}{|c|}{3} & 4 \\
\hline " & $"$ & " & \multicolumn{2}{|c|}{ within each sp. } & \multicolumn{2}{|c|}{5} & 7 \\
\hline " & " & "years w & ithin eac & h sp. & \multicolumn{2}{|c|}{4} & 6 \\
\hline " & two de & ermination & & & \multicolumn{2}{|c|}{23} & 30 \\
\hline
\end{tabular}


TABLE 2

Loss of Weight (Per cent) of Seedlings During Winter Storage in Cellar

\begin{tabular}{|c|c|c|c|c|c|c|c|}
\hline \multirow[b]{3}{*}{ Species } & \multirow{3}{*}{$\begin{array}{c}\text { Year } \\
\text { of } \\
\text { planting }\end{array}$} & \multicolumn{6}{|c|}{ Winter cellar storage } \\
\hline & & \multirow{2}{*}{$\begin{array}{l}\text { Heeled } \\
\text { in out- } \\
\text { of-doors }\end{array}$} & \multicolumn{2}{|c|}{ Peat around roots } & \multicolumn{2}{|c|}{ No peat } & \multirow[b]{2}{*}{ Mean } \\
\hline & & & $40^{\circ} \mathrm{F}$. & $35^{\circ} \mathrm{F}$. & $40^{\circ} \mathrm{F}$. & $35^{\circ} \mathrm{F}$. & \\
\hline \multirow{4}{*}{ Caragana } & 1952 & 5.2 & 1.1 & 3.1 & 18.6 & 29.6 & 11.5 \\
\hline & 1953 & 2.4 & 9.5 & 3.4 & 29.7 & 28.2 & 14.6 \\
\hline & 1954 & 2.3 & 8.7 & 12.5 & 25.6 & 24.2 & 14.7 \\
\hline & Mean & 3.3 & 6.4 & 6.3 & 24.6 & 27.3 & 13.6 \\
\hline \multirow[t]{4}{*}{$\overline{\text { Ash }}$} & 1952 & 1.8 & 0.0 & 0.1 & 14.5 & 17.3 & 6.7 \\
\hline & 1953 & 2.8 & 0.6 & 4.6 & 25.8 & 27.8 & 12.3 \\
\hline & 1954 & 1.6 & 9.3 & 10.1 & 23.4 & 21.0 & 13.1 \\
\hline & Mean & 2.1 & 3.3 & 4.9 & 21.2 & 22.0 & 10.7 \\
\hline \multirow{4}{*}{$\overline{\text { Box-elder }}$} & 1952 & 4.9 & 0.0 & 0.4 & 26.8 & 34.7 & 13.4 \\
\hline & 1953 & 8.6 & 4.2 & 4.9 & 29.6 & 35.9 & 16.6 \\
\hline & 1954 & 4.4 & 8.2 & 8.7 & 34.5 & 35.8 & 18.3 \\
\hline & Mean & 6.0 & 4.1 & 4.7 & 30.3 & 35.4 & 16.1 \\
\hline \multirow[t]{3}{*}{$\overline{\mathrm{Elm}}$} & 1953 & 2.1 & 2.7 & 4.1 & 30.3 & 30.0 & 13.8 \\
\hline & 1954 & 1.1 & 6.5 & 10.4 & 29.0 & 28.9 & 15.2 \\
\hline & Mean & 1.6 & 4.6 & 7.2 & 29.6 & 29.4 & 14.5 \\
\hline \multirow[t]{2}{*}{ Mean } & & 3.4 & 4.6 & 5.8 & 26.4 & 28.5 & 13.7 \\
\hline & & & & & \multicolumn{2}{|c|}{ P. .05} & P. .01 \\
\hline \multicolumn{5}{|c|}{ L.S.D. between means of species } & \multicolumn{2}{|c|}{1.6} & 2.1 \\
\hline & in & \multicolumn{3}{|c|}{ Cealinents } & \multicolumn{2}{|c|}{2.0} & 2.7 \\
\hline$"$ & $"$ & \multirow{2}{*}{\multicolumn{3}{|c|}{$"$ within each sp }} & \multirow{2}{*}{\multicolumn{2}{|c|}{3.2}} & 4.6 \\
\hline$"$ & $"$ & & & & & & 2.1 \\
\hline$"$ & two de & ermination & & & \multicolumn{2}{|c|}{$\begin{array}{l}1.0 \\
6.1\end{array}$} & 8.0 \\
\hline
\end{tabular}

this increase was small. Table 3 also shows marked survival differences between the closely related cottonwood and Volunteer.

Fungicides did not prevent molding. Isolations indicated that the molds were mainly species of Penicillium, Trichoderma, and Fusarium.

The data in Table 4 reveal that low survival of planted seedlings was associated with (i) high loss of weight during storage and (ii) increase of electrical conductance of water extracts during the storage period.

\section{Discussion}

The results in Table 1 demonstrated that seedlings of several broadleaved species can be successfully stored over winter in cellars. Weight loss of seedlings may be small, and subsequent field survival high, if the roots are kept packed in moist peat during storage. When the roots were not packed in 
peat (Table 1), weight loss of the seedlings was high and subsequent survival low. This may have been caused by metabolic processes, killing of plant tissues by pathogenic fungi, or by desiccation. Metabolic processes are not

TABLE 3

Field Survival (Per cent) of Seedlings and Cuttings as Afrected by Fungicidal Treatments Prior to Winter Cellar Storage

\begin{tabular}{|c|c|c|c|c|c|c|c|}
\hline Species & Tersan & Orthocide & Manzate & $\begin{array}{c}\text { Lime } \\
\text { sulphur }\end{array}$ & Semesan & $\begin{array}{c}\text { Water } \\
\text { (check) }\end{array}$ & Mean \\
\hline Caragana & 79 & 78 & 70 & 64 & 75 & 70 & 72.7 \\
\hline Ash & 72 & 64 & 62 & 27 & 46 & 59 & 55.0 \\
\hline Box-elder & 3 & 1 & 1 & 0 & 1 & 0 & 1.0 \\
\hline Elm & 10 & 17 & 9 & 3 & 19 & 7 & 10.8 \\
\hline Scots pine & 2 & 10 & 0 & 0 & 2 & 4 & 3.0 \\
\hline Cottonwood & d 7 & 13 & 2 & 3 & 7 & 4 & 6.0 \\
\hline Volunteer & 28 & 31 & 48 & 20 & 24 & 31 & 30.3 \\
\hline Mean & 28.7 & 30.6 & 27.4 & 16.7 & 24.8 & 25.0 & 25.5 \\
\hline & & & & & \multicolumn{2}{|c|}{ P. .05 } & P. .01 \\
\hline & & eans of tre & atments & & \multicolumn{2}{|r|}{4.6} & 6.0 \\
\hline , & $"$ & $" \quad$ spe & cies & & \multirow{2}{*}{\multicolumn{2}{|c|}{$\begin{array}{r}4.9 \\
12.1\end{array}$}} & 6.5 \\
\hline$"$ & tv & vo determir & gations & & & & 16.0 \\
\hline
\end{tabular}

TABLE 4

Relation Between Field Survival, Water loss, and Electrical Conductance of Water Extract in Seedlings Stored During Winter (1953 - 54) Under Two Treatments

\begin{tabular}{|c|c|c|c|c|c|}
\hline \multirow[b]{2}{*}{ Species } & \multirow[b]{2}{*}{ Storage treatment $t^{1}$} & \multirow{2}{*}{$\begin{array}{c}\text { Field } \\
\text { survival } \\
\text { (per cent) }\end{array}$} & \multirow{2}{*}{$\begin{array}{c}\text { Moisture } \\
\text { loss } \\
\text { (per cent) }\end{array}$} & \multicolumn{2}{|c|}{$\begin{array}{l}\text { Elec. conductance } \\
\text { (micromhos) }\end{array}$} \\
\hline & & & & Shoot & Root \\
\hline Caragana & $\begin{array}{l}\text { Peat around roots } \\
\text { No peat }\end{array}$ & $\begin{array}{l}94.0 \\
68.0\end{array}$ & $\begin{array}{l}10.6 \\
24.9\end{array}$ & $\begin{array}{l}319 \\
505\end{array}$ & $\begin{array}{l}1045 \\
2181\end{array}$ \\
\hline Ash & $\begin{array}{l}\text { Peat around roots } \\
\text { No peat }\end{array}$ & $\begin{array}{l}95.5 \\
26.0\end{array}$ & $\begin{array}{r}9.7 \\
22.2\end{array}$ & $\begin{array}{l}185 \\
226\end{array}$ & $\begin{array}{l}405 \\
536\end{array}$ \\
\hline Box-elder & $\begin{array}{l}\text { Peat around roots } \\
\text { No peat }\end{array}$ & $\begin{array}{r}80.0 \\
7.0\end{array}$ & $\begin{array}{r}8.4 \\
35.1\end{array}$ & $\begin{array}{l}336 \\
617\end{array}$ & $\begin{array}{l}1340 \\
2123\end{array}$ \\
\hline Elm & $\begin{array}{l}\text { Peat around roots } \\
\text { No peat }\end{array}$ & $\begin{array}{l}97.0 \\
13.5\end{array}$ & $\begin{array}{r}8.4 \\
28.9\end{array}$ & $\begin{array}{l}280 \\
389\end{array}$ & $\begin{array}{l}432 \\
842\end{array}$ \\
\hline Mean & $\begin{array}{l}\text { Peat around roots } \\
\text { No peat }\end{array}$ & $\begin{array}{l}91.6 \\
28.6\end{array}$ & $\begin{array}{r}9.3 \\
27.8\end{array}$ & $\begin{array}{l}280 \\
434\end{array}$ & $\begin{array}{r}805 \\
1420\end{array}$ \\
\hline
\end{tabular}

${ }^{1}$ All data are averages of two temperatures, $35^{\circ}$ and $40^{\circ} \mathrm{F}$., shown for 1954 in Tables 1 and 2. 
a likely cause since no differences occurred between the two temperatures tested. Metabolic processes are very low in dormant seedlings at temperatures lower than $40^{\circ} \mathrm{F}$. (5). The results of the fungicidal treatments (Table 3) suggest that the importance of pathogenic fungi was limited. The main factor obviously was water loss.

It was not determined in which part of the storage period the weight loss was greatest, i.e., whether loss of weight during the later warmer weeks of storage was proportionally greater than during the almost constant $30^{\circ}$ to $35^{\circ}$ F. winter temperatures. However, it was found in another, similar study (7) that molded box-elder grew very well if the stock was removed, moistened, wrapped as for shipping, and re-stored two weeks before planting. This indicates that desiccation in the latter part of the storage was critical. The porous peat may also have served as a thermal insulator at this critical period in spring. In lieu of the controlled uniform storage temperatures of $28^{\circ}$ to $30^{\circ} \mathrm{F}$. suggested by Kains and McQuesten (4), covering the roots with moist peat, Sphagnum, or other similar materials, may be used as a means of improving storage facilities. A frozen condition of the peat packing during winter storage was commonly observed, and this may be beneficial to the species tested. The better winter storage survival of Volunteer poplar compared with cottonwood, and of caragana and ash compared with box-elder and elm, also suggests that species and varieties of plants with ability to survive winter storage conditions could be selected.

Of the five fungicidal treatments, only Orthocide increased the survival of the plants. Apparently phytotoxicity of some of the fungicides reduced the survival. Nevertheless, even the least phytotoxic fungicide did not give survival equal to that of plants protected with peat. It appears that protection with peat without fungicidal treatments is a satisfactory storage method. The need to use fungicides with peat is lessened by the fact that acid peat suppresses fungal pathogens either directly or by encouraging certain saprophytes antagonistic to pathogens (9). Further investigations are needed to determine the importance of common antagonistic saprophytes such as Penicillium spp. and Trichoderma spp. (9), and the action of Fusarium spp. as a possible facultative pathogen on stored seedlings (10). Further studies will be required also to determine the effect of certain other low temperature fungi which, although of minor importance in the present instance, might adapt themselves to the special environment and become serious in cold storage.

Since electrical conductivity of the water extracts increased directly with plant weight loss (Table 4), increased electrical conductivity is a measure of drying out. High electrical conductivity has been correlated with freezing injury (8). This study shows that it is also correlated with desiccation injury. This suggests a simple and rapid method of determining the amount of desiccation that is occurring during winter storage. 


\section{REFERENCES}

1. BOYCE, JOHN SHAW. 1948. Forest pathology. 2nd ed. McGraw-Hill Book Co. Inc., New York.

2. ENGSTROM, H. E. and J. H. STOECKELER. 1941. Nursery practice for trees and shrubs on the prairie-plains. U.S. Dept, Agr. For. Serv. Misc. Pub. 434. p. 159.

3. HOLST, M. I. 1956. Scion storage and graft protection in the spring grafting of red pine. Can. Dept. Northern Affairs and Natl. Res. For. Branch, For. Res. Div. Tech. Note 29.

4. KAINS, M. B. and L. M. McQUESTEN. 1946. Propagation of plants. Orange Judd Publishing Co. Inc., New York.

5. MEYER, B. S. and D. B. ANDERSON. 1939. Plant physiology. 4th printing. D. Van Nostrand Co. Inc., New York.

6. SCHOPMEYER, C. S. 1940. Survival in forest plantation in the Northern Rocky Mountain Region. J. For. $38: 16-24$.

7. VAARTAJA, O. 1955. Storage moulding of maple seedlings. Can. Dept. Agr., For Biol. Div. Bi-Monthly Prog. Rept. $11(1): 3$.

8. WILNER, J. 1955. Results of laboratory tests for winter hardiness of woody plants by electrolytic methods. Proc. Amer. Soc. Hort. Sci. 66: 93-99.

9. WOOD, R. K. S. and M. TVEIT. 1955. Control of plant diseases by use of antagonistic organisms. Bot. Rev, 21: 441-492.

10. YOUNG, G. Y. 1943. Root rots in storage of deciduous nursery stock and their control. Phytopath. 33: 656-665. 